\title{
EFFICACY OF BIO-FOLIAR SPRAY ON GROWTH AND BIOCHEMICAL PARAMETERS OF DIFFERENT MULBERRY VARIETIES
}

\author{
${ }^{1}$ Dhiraj Kumar and ${ }^{2}$ R. Venkatesh Kumar \\ ${ }^{1}$ Department of Zoology, School of Life Sciences, Guru Ghasidas Vishwavidyalaya, \\ (A Central University), Bilaspur-495009 (C.G.), India \\ ${ }^{2}$ Department of Applied Animal Sciences, School of Biosciences and Biotechnology, \\ Babasaheb Bhimrao Ambedkar University, Lucknow-226025, India
}

Received 2013-12-10; Revised 2013-12-17; Accepted 2014-02-12

\begin{abstract}
The study was undertaken to improve the growth and biochemical contents in an instant available form through foliar combination of spirulina, soybean and vermiwash. 15,30 and $45 \mu \mathrm{g} \mathrm{mL}^{-1}$ concentrations of bio-foliar were sprayed on five different mulberry varieties namely S-1, S-146, S-1635, BR-2 and AR-14 to know their performance on growth parameters and biochemical constituents. Results of the investigation revealed that, among all experimental concentrations mulberry varieties and treatments, BR-2 and S-1635 varieties were performed well in respect of growth parameters and biochemical constituents. Highest leaf area $\left(234.07 \mathrm{~cm}^{2}\right)$ and total leaf yield per hectare (51.48 tons) was noticed in BR-2 mulberry variety at 45 $\mu \mathrm{g} \mathrm{mL} \mathrm{m}^{-1}$ followed by S-1635 variety. Further highest protein $\left(0.555 \mathrm{mg} \mathrm{g}^{-1}\right)$, carbohydrate $\left(0.668 \mathrm{mg} \mathrm{g}^{-1}\right)$, carotenoids $\left(0.550 \mathrm{mg} \mathrm{g}^{-1}\right)$, total chlorophyll $\left(2.04 \mathrm{mg} \mathrm{g}^{-1}\right)$ and crude protein content $(26.67 \%)$ were recorded at $45 \mu \mathrm{g} \mathrm{mL}^{-1}$ concentration by BR-2 variety followed with S-1635 variety as compare to control. The outcome of research implies that, among five mulberry varieties and concentrations, BR-2 and S-1635 varieties with $45 \mu \mathrm{g} \mathrm{mL}^{-1}$ concentration performed well and successfully augments the productivity and biochemical constituents of different mulberry varieties without any side effect.
\end{abstract}

Keywords: Bio-Foliar, Mulberry Varieties, Biochemicals and Productivity

\section{INTRODUCTION}

Mulberry leaf forms the basic food material for silkworm, Bombyx mori L. and nutrition is the most important growth regulating factor in silkworm, Bombyx mori L. Synthetic chemicals, fertilizers, pesticides, herbicides, growth promoters and other inputs though enhance productivity of mulberry but adversely affect the eco-system and increase prices of agricultural inputs (Patil et al., 2006). Under such circumstances the leaf quality may be improved by foliar application of soluble nutrients to mulberry leaves instantly (Shankar et al., 1999). Mulberry (Morus spp.) is a deep rooted high biomass producing foliage crop, responds well to foliar nutrition. Foliar application in right time increase level of application in specific nutrients to the leaf during growth and development (Narahari et al., 1997). Therefore, it is necessary that the nutrients applied to the mulberry through foliar nutrition are made easily available even at later stages of leaf development and it should be cost effective. To mitigate these difficulties proper mode of application of nutrients needs to be developed particularly by natural based formulations which are required in small quantities. Therefore, completely natural based formulation was made in the form bio-foliar and applied for the growth and productivity of mulberry. Bio-foliar is dominating over all kind of foliar sprays which were used for mulberry production due to its natural based product formulation. It is very cost effective, easily can be applied to mulberry Corresponding Author: Dhiraj Kumar, Department of Zoology, School of Life
(A Central University), Bilaspur-495009 (C.G.), India 
without harming mulberry ecosystem. Interesting point that for the first time all biological based organisms were used in the current study for making bio-foliar spray namely spirulina, soybean and Vermiwash. The present investigation was carried out to know the efficacy of eco-friendly bio-foliar spray on growth parameters and biochemical constituents of different mulberry varieties.

\section{MATERIALS AND METHODS}

\subsection{Procurement and Analysis of Samples}

Spirulina, vermiwash and soybeans were procured from University of Allahabad, Allahabad, Extension Centre of CIMAP, Lucknow and Beej Bhandar Kendra, Seed Market, Lucknow respectively.

Spirulina and soybean seeds were separately air-dried in the laboratory and ground to powder using an electric mixer grinder. About $450 \mathrm{~g}$ of the powdered material of each sample was macerated with $2800 \mathrm{~mL}$ of ethanol $(90 \%)$ for $72 \mathrm{~h}$. The extract was filtered and dried by evaporation in a water bath at $40^{\circ} \mathrm{C}$ to yield $16.94 \mathrm{~g}$ of the crude extract, which was used for the preparation of bio-foliar. Vermiwash was prepared as per the procedure described by Karuna et al. (1999). The collected vermiwash was centrifuged at $1000 \mathrm{rpm}$ and preserved into sterilized cane for further process. 15, 30 and 45 micrograms per milliliter $\left(\mu \mathrm{g} \mathrm{mL} \mathrm{mL}^{-1}\right)$ concentrations of bio-foliar were prepared with spirulina: Soybean: Vermiwash $(3: 2: 1, \mathrm{w} / \mathrm{v})$ and sprayed on five different mulberry varieties viz; S-1, S-146, S-1635, BR-2 and AR-14 to know their performance on growth and yield. Experiments were conducted three times with four replications in each treatment including control. Moisture percentage and moisture retaining capacity was estimated as defined by Dandin and Jolly (1986). Chlorophyll was estimated by the methodology of Hiscox and Israelstam (1979). Protein content in different mulberry varieties were estimated by method of Lowry et al. (1951) while carbohydrate content was estimated by Dubois et al. (1956) method.

\subsection{Statistical Analysis}

Data collected from all experiments with four replicates were subjected to statistical analysis. Two way Analysis of Variance (ANOVA) was carried out to find out the significant differences between the varieties and concentrations. Multiple Comparison of means were made depending on F-ratio and the Critical Difference (CD) values based on student $t$ criteria at 5 and $1 \%$ level of significance utilizing the standard methods (Johnson and Wichern, 2007). Pearson's Correlation Coefficients were also computed using the standard method in Statistics.
Computations were made using statistical package under M.S. Excel work sheet.

\section{RESULTS}

It was found that there were significant changes in the growth, yield and biochemical levels of mulberry due to bio-foliar application of different concentrations on mulberry varieties.

\subsection{Effect of Bio-Foliar Spray on Growth of Mulberry Varieties}

Results of the present investigations indicated that the different varieties of mulberry did not show any significant effect on shoot length, number of shoot per plant, number of leaves per plant, internodal distance and leaf area after spraying bio-foliar in 10 and 20 days interval. However, the trend improved significantly with same mulberry varieties when treated with $45 \mu \mathrm{g} \mathrm{mL}$ concentration of bio-foliar spray after 30 and 40 days.

Among mulberry varieties and treatments, S-1 variety was recorded longest shoot length $(103.13 \mathrm{~cm})$ and number of leaves per plant (399.00) with $45 \mu \mathrm{g} \mathrm{mL}^{-1}$ as compared to other concentrations. All the treated mulberry varieties have significantly (df:4\&12, p:9.46) higher shoot length and number of leaves per plant compared over control.

Number of shoots per plant have increased with S146 variety $(30.50)$ at $45 \mu \mathrm{g} \mathrm{mL}$ of bio-foliar, whereas BR-2 variety showed the largest leaf area $\left(234.07 \mathrm{~cm}^{2}\right)$ and minimum inter nodal distance $(5.74$ $\mathrm{cm})$ at $45 \mu \mathrm{g} \mathrm{mL}^{-1}$ when compared to other concentrations and control (Table 1a).

\subsection{Effect of Bio-Foliar Spray on Yield of Mulberry Varieties}

Observations revealed that highest fresh weight of leaves $(475.86 \mathrm{~g})$, leaf yield per plant $(2.15 \mathrm{~kg})$ and total leaf yield per hectare (51.48 tons) was noticed in BR-2 mulberry variety at $45 \mu \mathrm{g} \mathrm{mL} \mathrm{m}^{-1}$ followed by S-1635 variety as compared to 15 and $30 \mu \mathrm{g} \mathrm{mL}^{-1}$ and control. Therefore, the current study clearly revealed that growth and yield of different mulberry varieties were significantly (df:4\&12, p: 7.15) enhanced by $45 \mu \mathrm{g} \mathrm{mL}^{-1}$ concentration of bio-foliar formulation (Table 1b).

\subsection{Effect of Bio-Foliar Spray on Protein and Carbohydrate Content of Mulberry Varieties}

Significantly (df:4\&12,p:1.63) increased protein content was noted in $45 \mu \mathrm{g} \mathrm{mL}^{-1}$ concentration of bio-foliar spray in AR-14 (0.523 mg g $\left.{ }^{-1}\right)$ and BR-2 $\left(0.555 \mathrm{mg} \mathrm{g}^{-1}\right)$ varieties as compared to the rest of the concentrations. 
Dhiraj Kumar and R. Venkatesh Kumar / OnLine Journal of Biological Sciences 14 (1): 64-69, 2014

Table 1a. Effect of bio-foliar spray on growth and yield of different mulberry varieties

\begin{tabular}{|c|c|c|c|c|c|c|c|c|c|c|c|c|c|c|c|}
\hline \multirow[b]{2}{*}{$\begin{array}{l}\text { Mulberry } \\
\text { variety }\end{array}$} & \multicolumn{4}{|c|}{ Shoot length $(\mathrm{cm})$} & \multirow[b]{2}{*}{$\begin{array}{l}\text { Mean } \\
\mathrm{mL}^{-1}\end{array}$} & \multicolumn{4}{|c|}{ No. of shoots/plant } & \multirow[b]{2}{*}{$\begin{array}{l}\text { Mean } \\
\mathrm{mL}^{-1}\end{array}$} & \multicolumn{4}{|c|}{ No. of leaves/plant } & \multirow[b]{2}{*}{$\begin{array}{l}\text { Mean } \\
\mathrm{mL}^{-1}\end{array}$} \\
\hline & $\begin{array}{l}15 \mu \mathrm{g} \\
\mathrm{mL}^{-\mathrm{p}}\end{array}$ & $\begin{array}{l}30 \mu \mathrm{g} \\
\mathrm{mL}^{-1}\end{array}$ & $\begin{array}{l}45 \mu \mathrm{g} \\
\mathrm{mL}^{-1}\end{array}$ & $\begin{array}{l}\text { Control } \\
\mathrm{mL}^{-1}\end{array}$ & & $\begin{array}{l}15 \mu \mathrm{g} \\
\mathrm{mL}^{-\mathrm{P}}\end{array}$ & $\begin{array}{l}30 \mu \mathrm{g} \\
\mathrm{mL}^{-\mathrm{P}}\end{array}$ & $\begin{array}{l}45 \mu \mathrm{g} \\
\mathrm{mL}^{-\mathrm{p}}\end{array}$ & $\begin{array}{l}\text { Control } \\
\mathrm{mL}^{-1}\end{array}$ & & $\begin{array}{l}15 \mu \mathrm{g} \\
\mathrm{mL}^{-1}\end{array}$ & $\begin{array}{l}30 \mu \mathrm{g} \\
\mathrm{mL}^{-1}\end{array}$ & $\begin{array}{l}45 \mu \mathrm{g} \\
\mathrm{mL}^{-1}\end{array}$ & $\begin{array}{l}\text { Control } \\
\mathrm{mL}^{-1}\end{array}$ & \\
\hline S-1 & 92.200 & 96.75 & 103.130 & 89.31 & 95.350 & 17.75 & 22.50 & 24.250 & 18.50 & 20.750 & 340.000 & 341.25 & 399.000 & 330.50 & 352.690 \\
\hline S-146 & 61.6600 & 64.90 & 72.850 & 58.83 & 64.560 & 24.00 & 25.50 & 30.500 & 22.00 & 25.500 & 260.750 & 270.50 & 287.000 & 252.75 & 267.750 \\
\hline S-1635 & 81.9400 & 85.28 & 100.650 & 81.17 & 87.260 & 21.00 & 23.00 & 25.500 & 20.00 & 22.380 & 289.250 & 303.25 & 325.250 & & 300.810 \\
\hline AR-14 & 77.500 & 80.14 & 82.510 & 76.61 & 79.190 & 18.00 & 18.75 & 20.000 & 16.00 & 18.190 & 216.000 & 218.25 & 224.250 & 209.50 & 217.000 \\
\hline BR-2 & 62.400 & 65.08 & 74.280 & 62.09 & 65.960 & 21.25 & 24.00 & 27.500 & 20.25 & 23.250 & 200.500 & 213.75 & 237.750 & 188.50 & 210.130 \\
\hline CD@5\% & 0.998 & & 0.893 & & 1.997 & 0.717 & & 0.642 & & 1.435 & 4.091 & & 3.659 & & 8.181 \\
\hline CD@1\% & 1.328 & & 1.188 & & 2.656 & 0.954 & & 0.853 & & 1.908 & 5.44 & & 4.866 & & 10.881 \\
\hline
\end{tabular}

Table 1b. Effect of bio-foliar spray on growth and yield of different mulberry varieties

\begin{tabular}{|c|c|c|c|c|c|c|c|c|c|c|c|c|c|c|c|}
\hline \multirow[b]{2}{*}{$\begin{array}{l}\text { Mulberry } \\
\text { variety }\end{array}$} & \multicolumn{4}{|c|}{ Internodal distance $(\mathrm{cm})$} & \multirow[b]{2}{*}{$\begin{array}{l}\text { Mean } \\
\mathrm{mL}^{-1}\end{array}$} & \multicolumn{4}{|c|}{ Wt. of 100 fresh mulberry leaves $(\mathrm{g})$} & \multirow[b]{2}{*}{$\begin{array}{l}\text { Mean } \\
\mathrm{mL}^{-1}\end{array}$} & \multicolumn{4}{|c|}{ Leaf yield/hectare/year (tons) } & \multirow[b]{2}{*}{$\begin{array}{l}\text { Mean } \\
\mathrm{mL}^{-1}\end{array}$} \\
\hline & $\begin{array}{l}15 \mu \mathrm{g} \\
\mathrm{mL}^{-1}\end{array}$ & $\begin{array}{l}30 \mu \mathrm{g} \\
\mathrm{mL}^{-1}\end{array}$ & $\begin{array}{l}45 \mu \mathrm{g} \\
\mathrm{mL}^{-1}\end{array}$ & $\begin{array}{l}\text { Control } \\
\mathrm{mL}^{-1}\end{array}$ & & $\begin{array}{l}15 \mu \mathrm{g} \\
\mathrm{mL}^{-1}\end{array}$ & $\begin{array}{l}30 \mu \mathrm{g} \\
\mathrm{mL}^{-1}\end{array}$ & & & & $\begin{array}{l}15 \mu \mathrm{g} \\
\mathrm{mL}^{-1}\end{array}$ & & & & \\
\hline S-1 & 5.620 & 5.85 & & & 5.640 & & & & & & & & & & 31.090 \\
\hline & & 5.86 & & 5.22 & & & & & & & & & & & \\
\hline & 6.730 & 6.89 & 7.400 & 6.48 & 870 & & 387.31 & 403.2 & & & & 42.8 & & 3 & 1.860 \\
\hline & & & & & & & & & & & & & & & \\
\hline & & 5.72 & 0 & 5.74 & & & 462.87 & & 423.25 & & & 41.92 & & 38.99 & \\
\hline & & & & & & & & & & & & & & & \\
\hline CD @ $1 \%$ & 0.100 & & 0.090 & & 0.200 & 2.084 & & 1.864 & & 4.168 & 0.700 & & 0.626 & & 1.399 \\
\hline
\end{tabular}

Table 2a. Effect of bio-foliar spray on biochemicals of different mulberry varieties

\begin{tabular}{|c|c|c|c|c|c|c|c|c|c|c|c|c|c|c|c|}
\hline \multirow[b]{2}{*}{$\begin{array}{l}\text { Mulberry } \\
\text { variety }\end{array}$} & \multicolumn{4}{|c|}{ Protein content $(\mathrm{mg} / \mathrm{g})$} & \multirow[b]{2}{*}{$\begin{array}{l}\text { Mean } \\
\mathrm{mL}^{-1}\end{array}$} & \multicolumn{4}{|c|}{ Carbohydrate content $(\mathrm{mg} / \mathrm{g})$} & \multirow[b]{2}{*}{$\begin{array}{l}\text { Mean } \\
\mathrm{mL}^{-1}\end{array}$} & \multicolumn{4}{|c|}{ Carotenoids content $(\mathrm{mg} / \mathrm{g})$} & \multirow[b]{2}{*}{$\begin{array}{l}\text { Mean } \\
\mathrm{mL}^{-1}\end{array}$} \\
\hline & $\begin{array}{l}15 \mu \mathrm{g} \\
\mathrm{mL}^{-1}\end{array}$ & $\begin{array}{l}30 \mu \mathrm{g} \\
\mathrm{mL}^{-1}\end{array}$ & $\begin{array}{l}45 \mu \mathrm{g} \\
\mathrm{mL}^{-1}\end{array}$ & $\begin{array}{l}\text { Control } \\
\mathrm{mL}^{-1}\end{array}$ & & $\begin{array}{l}15 \mu \mathrm{g} \\
\mathrm{mL}^{-1}\end{array}$ & $\begin{array}{l}30 \mu \mathrm{g} \\
\mathrm{mL}^{-1}\end{array}$ & $\begin{array}{l}45 \mu \mathrm{g} \\
\mathrm{mL}^{-1}\end{array}$ & $\begin{array}{l}\text { Control } \\
\mathrm{mL}^{-1}\end{array}$ & & $\begin{array}{l}15 \mu \mathrm{g} \\
\mathrm{mL}^{-1}\end{array}$ & $\begin{array}{l}30 \mu \mathrm{g} \\
\mathrm{mL}^{-1}\end{array}$ & $\begin{array}{l}45 \mu \mathrm{g} \\
\mathrm{mL}^{-1}\end{array}$ & $\begin{array}{l}\text { Control } \\
\mathrm{mL}^{-1}\end{array}$ & \\
\hline S-1 & 0.41 & 0.448 & 0.488 & 0.405 & 0.438 & 0.521 & 0.553 & 0.562 & 0.508 & 0.536 & 0.379 & 0.394 & 0.431 & 0.367 & 0.393 \\
\hline S-146 & 0.484 & 0.498 & 0.509 & 0.476 & 0.492 & 0.395 & 0.419 & 0.433 & 0.384 & 0.408 & 0.510 & 0.510 & 0.514 & 0.503 & 0.509 \\
\hline S-1635 & 0.461 & 0.524 & 0.534 & 0.457 & 0.494 & 0.559 & 0.560 & 0.669 & 0.547 & 0.584 & 0.533 & 0.541 & 0.535 & 0.490 & 0.525 \\
\hline AR-14 & 0.513 & 0.514 & 0.523 & 0.513 & 0.516 & 0.495 & 0.515 & 0.532 & 0.471 & 0.503 & 0.485 & 0.500 & 0.511 & 0.435 & 0.483 \\
\hline BR-2 & 0.434 & 0.548 & 0.555 & 0.432 & 0.492 & 0.516 & 0.525 & 0.668 & 0.514 & 0.556 & 0.523 & 0.542 & 0.550 & 0.527 & 0.535 \\
\hline CD @5\% & 0.001 & & 0.001 & & 0.002 & 0.004 & & 0.003 & & 0.007 & 0.005 & & 0.005 & & 0.011 \\
\hline CD@1\% & 0.001 & & 0.001 & & 0.003 & 0.005 & & 0.004 & & 0.010 & 0.007 & & 0.006 & & 0.014 \\
\hline
\end{tabular}

Table 2b. Effect of bio-foliar spray on biochemicals of different mulberry varieties

\begin{tabular}{|c|c|c|c|c|c|c|c|c|c|c|c|c|c|c|c|}
\hline \multirow[b]{2}{*}{$\begin{array}{l}\text { Mulberry } \\
\text { variety }\end{array}$} & \multicolumn{4}{|c|}{ Chlorophyll 'a' (mg/g) } & \multirow[b]{2}{*}{$\begin{array}{l}\text { Mean } \\
\mathrm{mL}^{-1}\end{array}$} & \multicolumn{4}{|c|}{ Chlorophyll 'b' (mg/g) } & \multirow[b]{2}{*}{$\begin{array}{l}\text { Mean } \\
\mathrm{mL}^{-1}\end{array}$} & \multicolumn{4}{|c|}{ Total chlorophyll (mg/g) } & \multirow[b]{2}{*}{$\begin{array}{l}\text { Mean } \\
\mathrm{mL}^{-1}\end{array}$} \\
\hline & $\begin{array}{l}15 \mu \mathrm{g} \\
\mathrm{mL}^{-1}\end{array}$ & $\begin{array}{l}30 \mu \mathrm{g} \\
\mathrm{mL}^{-1}\end{array}$ & $\begin{array}{l}45 \mu \mathrm{g} \\
\mathrm{mL}^{-1}\end{array}$ & $\begin{array}{l}\text { Control } \\
\mathrm{mL}^{-1}\end{array}$ & & $\begin{array}{l}15 \mu \mathrm{g} \\
\mathrm{mL}^{-1}\end{array}$ & $\begin{array}{l}30 \mu \mathrm{g} \\
\mathrm{mL}^{-1}\end{array}$ & $\begin{array}{l}45 \mu \mathrm{g} \\
\mathrm{mL}^{-1}\end{array}$ & $\begin{array}{l}\text { Control } \\
\mathrm{mL}^{-1}\end{array}$ & & $\begin{array}{l}15 \mu \mathrm{g} \\
\mathrm{mL}^{-1}\end{array}$ & $\begin{array}{l}30 \mu \mathrm{g} \\
\mathrm{mL}^{-1}\end{array}$ & $\begin{array}{l}45 \mu \mathrm{g} \\
\mathrm{mL}^{-1}\end{array}$ & $\begin{array}{l}\text { Control } \\
\mathrm{mL}^{-1}\end{array}$ & \\
\hline S-1 & 0.644 & 0.683 & 0.683 & 0.706 & 0.679 & 0.980 & 0.97 & 1.040 & 0.87 & 0.96 & 1.628 & 1.657 & 1.723 & 1.582 & 1.640 \\
\hline S-146 & 0.674 & 0.679 & 0.696 & 0.704 & 0.688 & 1.250 & 1.24 & 1.260 & 0.97 & 1.18 & 1.928 & 1.920 & 1.963 & 1.676 & 1.870 \\
\hline S-1635 & 0.675 & 0.691 & 0.682 & 0.698 & 0.686 & 1.230 & 1.26 & 1.240 & 1.17 & 1.23 & & 1.9 & 1.929 & & 1.910 \\
\hline AR-14 & 0.834 & 0.831 & 0.852 & 0.840 & 0.839 & 0.970 & 1.09 & 0.990 & 0.92 & 0.99 & 1.811 & 1.923 & 1.851 & & 1.830 \\
\hline BR-2 & 0.680 & 0.688 & 0.681 & 0.677 & 0.681 & 1.330 & 1.34 & 1.360 & 1.32 & 1.34 & 2.016 & 2.028 & 2.046 & 2.002 & 2.020 \\
\hline CD@5\% & 0.004 & & 0.003 & & 0.007 & 0.013 & & 0.012 & & 0.026 & 0.012 & & 0.010 & & 0.023 \\
\hline CD@1\% & 0.005 & & 0.004 & & 0.009 & 0.017 & & 0.016 & & 0.035 & 0.015 & & 0.014 & & 0.031 \\
\hline
\end{tabular}

Table 2c. Effect of bio-foliar spray on biochemicals of different mulberry varieties

\begin{tabular}{|c|c|c|c|c|c|c|c|c|c|c|c|c|c|c|c|}
\hline \multirow[b]{2}{*}{$\begin{array}{l}\text { Mulberry } \\
\text { variety }\end{array}$} & \multicolumn{4}{|c|}{ Moisture content (\%) } & \multirow[b]{2}{*}{$\begin{array}{l}\text { Mean } \\
\mathrm{mL}^{-1}\end{array}$} & \multicolumn{4}{|c|}{ MRC (\%) } & \multirow[b]{2}{*}{$\begin{array}{l}\text { Mean } \\
\mathrm{mL}^{-1}\end{array}$} & \multicolumn{4}{|c|}{ Crude protein (\%) } & \multirow[b]{2}{*}{$\begin{array}{l}\text { Mean } \\
\mathrm{mL}^{-1}\end{array}$} \\
\hline & $\begin{array}{l}15 \mu \mathrm{g} \\
\mathrm{mL}^{-1}\end{array}$ & $\begin{array}{l}30 \mu \mathrm{g} \\
\mathrm{mL}^{-1}\end{array}$ & $\begin{array}{l}45 \mu \mathrm{g} \\
\mathrm{mL}^{-1}\end{array}$ & $\begin{array}{l}\text { Control } \\
\mathrm{mL}^{-1}\end{array}$ & & $\begin{array}{l}15 \mu \mathrm{g} \\
\mathrm{mL}^{-1}\end{array}$ & $\begin{array}{l}30 \mu \mathrm{g} \\
\mathrm{mL}^{-1}\end{array}$ & $\begin{array}{l}45 \mu \mathrm{g} \\
\mathrm{mL}^{-1}\end{array}$ & $\begin{array}{l}\text { Control } \\
\mathrm{mL}^{-1}\end{array}$ & & $\begin{array}{l}15 \mu \mathrm{g} \\
\mathrm{mL}^{-1}\end{array}$ & $\begin{array}{l}30 \mu \mathrm{g} \\
\mathrm{mL}^{-1}\end{array}$ & $\begin{array}{l}45 \mu \mathrm{g} \\
\mathrm{mL}^{-1}\end{array}$ & $\begin{array}{l}\text { Control } \\
\mathrm{mL}^{-1}\end{array}$ & \\
\hline S-1 & 73.11 & 74.66 & 74.400 & 73.36 & 73.88 & 54.07 & 59.15 & 59.82 & 54.16 & 56.80 & 24.18 & 26.35 & 26.81 & 22.45 & 24.950 \\
\hline S-146 & 73.05 & 73.77 & 75.660 & 71.38 & 73.46 & 52.35 & 54.51 & 57.81 & 51.67 & 54.08 & 21.85 & 23.51 & 24.78 & 21.59 & 22.930 \\
\hline S-1635 & 71.18 & 72.79 & 74.810 & 72.01 & 72.70 & 51.29 & 54.45 & 55.78 & 51.72 & 53.31 & 24.31 & 25.64 & 25.98 & 22.66 & 24.600 \\
\hline AR-14 & 77.14 & 78.20 & 80.690 & 75.90 & 77.98 & 51.86 & 54.39 & 57.95 & 52.60 & 54.20 & 22.18 & 23.23 & 24.21 & 22.01 & 22.910 \\
\hline BR-2 & 74.79 & 77.98 & 77.870 & 73.37 & 76.00 & 61.25 & 64.89 & 64.94 & 60.05 & 62.78 & 23.75 & 26.10 & 26.67 & 22.50 & 24.750 \\
\hline CD @5\% & 0.934 & & 0.835 & & - & 0.88 & & 0.787 & & - & 0.176 & & 0.157 & & 0.351 \\
\hline CD@1\% & 1.242 & & 1.110 & & - & 1.17 & & 1.047 & & - & 0.234 & & 0.209 & & 0.467 \\
\hline
\end{tabular}


The control of all varieties showed least protein content compared to treated varieties. Similar increased carbohydrate content $\left(0.669\right.$ and $\left.0.668 \mathrm{mg} \mathrm{g}^{-1}\right)$ was observed in S-1635 and BR-2 varieties respectively with $45 \mu \mathrm{g} \mathrm{mL}$ of bio-foliar application. Crude protein content was also shown to be the highest in BR2 variety at $45 \mu \mathrm{g} \mathrm{mL}^{-1}$ concentration as compared to control. Control of all mulberry varieties here again showed least moisture content, moisture retention and crude protein as well (Table $\mathbf{2 a}$ ).

\subsection{Alteration of Carotenoid, Total Chlorophyll, Chlorophyll a and Chlorophyll b Content in Mulberry Varieties}

Bio-foliar exerted significant (df:4\&12,p: 4.75) influence on carotenoids contents. The increased carotenoids content $\left(0.550 \mathrm{mg} \mathrm{g}^{-1}\right)$ was observed in BR-2 variety at $45 \mu \mathrm{g} \mathrm{mL}^{-1}$ followed by $\mathrm{S}-1635$ variety, while control of all varieties showed least content of carotenoids.

The highest chlorophyll 'a' (0.852 $\left.\mathrm{mg} \mathrm{g}^{-1}\right)$, chlorophyll 'b' (1.365 $\left.\mathrm{mg} \mathrm{g}^{-1}\right)$ and total chlorophyll (2.046 $\mathrm{mg} \mathrm{g}^{-1}$ ) was recorded for AR-14 and BR-2 varieties respectively at $45 \mu \mathrm{g} \mathrm{mL}^{-1}$ concentration when compared to other concentrations and control. Chlorophyll was found highly significant (df: 4\&12, p: 1.11) with bio-foliar application on different mulberry varieties at $45 \mu \mathrm{g} \mathrm{mL}^{-1}$ (Table $\mathbf{2 b}$ ).

\subsection{Effect of Bio-Foliar Spray on Moisture Retention in Mulberry Varieties}

Results indicated that leaf moisture did not show significant (df:4\&12, p:6.37) interaction between varieties and various concentrations of bio-foliar. Highest moisture content $(80.69 \%)$ was observed in AR-14 variety at $45 \mu \mathrm{g}$ $\mathrm{mL}^{-1}$ concentration. Nevertheless, maximum moisture retention capacity $(64.94 \%)$ was noticed with BR-2 variety at $45 \mu \mathrm{g} \mathrm{mL}^{-1}$ concentration (Table $2 \mathrm{c}$ ).

\section{DISCUSSION}

With regard to effect of bio-foliar application, among all mulberry varieties and treatments, S-1 variety has recorded longest shoot length of $103.13(\mathrm{~cm})$ with $45 \mu \mathrm{g}$ $\mathrm{mL}^{-1}$ and it is found to be beneficial over other treatments. The results are in accordance with those of Pramod et al. (1999), who opined that higher concentration of foliar application of salicylic acid induced maximum shoot length in soybean. Internodal distance of a variety is one of the parameters which contribute to the total leaf produced by each plant.
Yokoyama (1975) reported that mulberry leaf yield depends on the number and length of the shoots, internodal distance and number and weight of leaves per plant. Fotadar et al. (1989) reported that inter nodal distance is an important genotypic attribute which influences the total foliage produced by a plant. Lesser inter nodal distance more will be the number of the inter nodes per plant and in turn more number of leaves per plant. The results are in accordance with those of Moose and Sisco (1994), who have amply demonstrated the most pronounced physiological effect of gibberellins in stem elongation particularly at the elongation of internodes. In the present study, highest leaf area was recorded for BR-2 and S-1635 under bio-foliar treatment at $45 \mu \mathrm{g} \mathrm{mL}$, which is due to increased of photosynthesis leading to enhanced leaf area and as well better utilization of stored carbohydrates. The results are in accordance with those of Watson (1952) who viewed that different levels of salicylic acid perform better with respect to number of leaves and lamina, which might be due to increasing of photosynthesis leading to enhanced leaf area index. Leaf weight is considered as a more precise index for yield assessment, as leaf to cocoon ratio is calculated by weight (Dandin and Kumar, 1986). Hamada (1956) reported that the yield of mulberry leaves depends upon the length of the shoot and leaf weight. Maximum leaf weight was recorded in BR-2 variety at $45 \mu \mathrm{g} \mathrm{mL}^{-1}$ concentration which is due to increased of photosynthesis leading to enhanced leaf area as well as better utilization of stored carbohydrates.

Highest leaf yield was recorded at $45 \mu \mathrm{g} \mathrm{mL}^{-1}$ of biofoliar spray. Bio-foliar induced promontory effect due presence of growth inducing substances, essential amino acids, vitamins and plant nutrients. The results are in accordance with Singhvi et al. (2001) who have reported that $15.17(\%)$ leaf yield was increased by the foliar application of salicylic acid in mulberry.

The improvement in the protein content is directly reflected on the leaf yield. Protein is the main constituent of the mulberry leaf, which contributes for the synthesis of silk (Kawase and Michihiro, 1976) and this improvement indicates the effect of foliar spray. These results are in conformity with Loknath and Shivashankar (1986). Thus, from the study it is concluded that among the four spray formulations including control, $45 \mu \mathrm{g}$ $\mathrm{mL}^{-1}$ of bio-foliar spray recorded significant improvement in leaf yield and quality of mulberry. As the concentration of bio-foliar spray was enhanced, leaf yield of different mulberry varieties was also increased due to absorption of higher quantity plant nutrients, antioxidants, vitamins and amino acids because they major constituent of bio-foliar spray which is required for higher growth and productivity of mulberry. 
Application of bio-foliar on different mulberry varieties brought a significant increase in the chlorophyll content of leaves over control. Among all mulberry varieties and bio-foliar treatments, BR-2 variety has shown highly significant values $(\mathrm{p}>0.01)$, highest total chlorophyll was recorded at $45 \mu \mathrm{g} \mathrm{mL}{ }^{-1}$ concentration followed by $30,15 \mu \mathrm{g} \mathrm{mL}^{-1}$ and control. This is due to an increase in the $\mathrm{Fe}$ and $\mathrm{Mg}$ content of mulberry leaves. The increase in chlorophyll content with bio-foliar spray confirmed the reports of Singhvi et al. (2001) in mulberry and Gunes et al. (2007) for maize. Further, Baky et al. (2014) showed higher increasement of total chlorophyll, chlorophyll a and b and antioxidant lowmolecular compounds i.e., glutathione and carotenoids contents by foliar application of green algae and blue green algae (Spirulina).

Bio-foliar spray contributed well for leaf moisture when treated with $45 \mu \mathrm{g} \mathrm{mL}{ }^{-1}$ concentration. The higher moisture content in the leaves of AR-14 mulberry variety was noticed due to the additional supply of nutrition (biofoliar) to the leaves and also withstanding the moisture for longer duration. This phenomenon attributed to the fact that bio-foliar application can increase the leaf diffusive resistance and lower transpiration rates. The increased water content in plants treated with foliar spray were also reported for other crops grown under salt stress i.e., barley (El-Tayeb, 2005), tomato (Tari et al., 2002; Szepesi et al., 2005) and cucumber (Yildirim et al., 2008).

Among all mulberry varieties and concentrations, S1635 variety showed highest carbohydrate content at $45 \mu \mathrm{g}$ $\mathrm{mL}^{-1}$ concentration of bio-foliar spray over control. The present observations are in close conformity with findings of Gowda et al. (2000) who reported soil application of DAP to mulberry, with foliar application of seriboost to mulberry which increased the total carbohydrates.

Improvement in crude protein was mainly attributed to the foliar spray where nutrients were rapidly absorbed by foliage and evidently the plant metabolism or assimilation have been activated thus contributing for healthy green foliage resulting in synthesis of organic contents.

The results obtained from the proposed study clearly showed that the varieties namely BR-2 and S-1635 emerged as top priority varieties by enhancing biochemical constituents and productivity.

\section{CONCLUSION}

It is clearly concluded that bio-foliar application of $45 \mu \mathrm{g} \mathrm{mL}^{-1}$ concentration on BR-2 and S-1635 mulberry varities was an effective treatment for growth and productivity of mulberry and it is also able to enhance biochemical constituents of different mulberry varieties without causing any substantial loss to ecosystem.

\section{ACKNOWLEDGEMENT}

Researchers are indebted to Dr. M.N. Ananthraman, Statistical Officer, KSSR\&DI, Bangalore for his support in statistical analysis of the research data. We are also thankful to UGC, New Delhi for providing financial assistance.

\section{REFERENCES}

Baky, H.H.A.E., M.M. Hussein and G.S. El-Baroty, 2014. Induces of antioxidant compounds and salt tolerance in wheat plant, irrigated with seawater as response to application of microalgae spray. Am. J. Agric. Biol. Sci., 9: 127-137. DOi: 10.3844/ajabssp.2014.127.137

Dandin, S.B. and M.S. Jolly, 1986. Mulbery descriptor. Sericologia, 26: 465-475.

Dubois, M., K.A. Gilles, J.K. Hamilton, P.A. Rebers and F. Smith, 1956. Colorimetric method for determination of sugars and related substances. Anal. Chem., 28: 350-356. DOI: 10.1021/ac60111a017

El-Tayeb, M.A., 2005. Response of barley grains to the interactive e.ect of salinity and salicylic acid. Plant Growth Regulat., 45: 215-224. DOi: 10.1007/s10725-005-4928-1

Fotadar, R.K., M.N. Ahsan, K.L. Dhar and B.S. Bhakuni, 1989. Evaluation and utilization of genetic variability in mulberry. Ind. J. Sericulture, 28: $150-158$.

Gowda, R., P. Sundar and B.V. Raghu, 2000. Foliar spray of seriboost on mulberry and its impact on cocoon production. Proc. Natl. Seminar Tropical Sericulture, Bangalore, 2: 163-167.

Gunes, A., M. Alapaslan, F. Eraslan, E.C. Bagci and N. Cicek, 2007. Salicylic acid induced changes on some physiological parameters symptomatic for oxidative stress and mineral nutrition in maize (Zea mays L.) grown under salinity. J. Plant Physiol., 164: 728-736. DOI: 10.1016/j.jplph.2005.12.009

Hamada, S., 1956. Principles in high-yield mulberry culture. Rev. Du. Ver. A Soie, 8: 125-132.

Hiscox, J.D. and G.F. Israelstam, 1979. A method for the extraction of chlorophyll from leaf tissue without maceration. Canad. J. Botany, 57: 1332-1334. DOI: 10.1139/b79-163 
Johnson, R.A. and D.W. Wichern, 2007. Applied Multivariate Statistical Analysis. 7th Edn., Pearson Prentice Hall, Upper Saddle River, ISBN-10: 0131877151, pp: 773.

Karuna, K., C.R. Patil, P. Narayanswamy and R.D. Kale, 1999. timulatory effect of earthworm body fluid vermiwash on crinkle Red variety of Anthurium andreanum Lind. Crop Res., 17: 253-257.

Kawase, S. and K. Michihiro, 1976. Small molecular weight DNA of the silkworm. Bombyx Mori. Insect Biochem., 6: 355-362. DOI: 10.1016/00201790(76)90036-6

Loknath, R. and K. Shivasankar, 1986. Effect of foliar application of micronutrients and magnesium on the growth, yield and quality of mulberry (Morus alba). Ind. J. Sericulture, 25: 1-5.

Lowry, O.H., N.J. Rosenbrough, A.L. Farr and R.J. Randall, 1951. Protein measurement with folinphenol reagent. J. Biol. Chem., 193: 265-275. PMID: 14907713

Moose, S.P. and P.H. Sisco, 1994. Glossy Z5 controls the epidermal juvenile-to-adult phase transition in maize. Plant Cell, 6: 1343-1355.

Narahari, R., B.V. Krishna, M. Chaluvachari and U.D. Bongale, 1997. Effect of certain foliar spray formulations on growth and leaf yield of mulberry under rainfed conditions. Proceedings of the National Conference on Moriculture, Physiological, Biochemical and Molecular Aspects of Stress Tolerance in Mulberry, India.

Patil, S.S., S.B. Kengar and T.V. Sathe, 2006. A new vermiwash model for sustainable agriculture. Proceedings of the Asia Pacific Congress of Sericulture and Insect Biotechnollgy, (SIB ' 06), Korea.
Pramod, K., S.D. Dubeand and V.S. Chauhan, 1999. Effect of salicylic acid on growth, development and some biochemical aspects of soybean Glycine max L. Merrill. Ind. J. Plant Physiol., 4: 327-330.

Shankar, M.A., A. Peter and B.T. Rangaswamy, 1999. Mulberry Nutrition Focus on New Concepts. In: Advances in Mulberry Sericulture, Devaiah, M.C., K.C. Narayanaswamy and V.G. Maribashetty (Eds.), CVG Publications, India.

Singhvi, N.R., J. Kodandaramaiah, M. Rekha, A. Sarkar and R.K. Datta, 2001. Effect of salicylic acid on leaf yield and pigment content in mulberry Morus spp. Ind. J. Sericult., 40: 100-102.

Szepesi, A., J. Siszar, S. Bajkan, K. Gemes and F. Horvath et al., 2005. Role of salicylic acid pretreatment on the acclimation of tomato plants to salt and osmotic stress. Acta Biol. Szegediensis, 49: 123-125.

Tari, I., J. Csiszar, S. Gabriella, F. Horvath and A. Pecsvaradi et al., 2002. Acclimation of tomato plants to salinity stress after a salicylic acid pre treatment. Acta Biol. Szegediensis, 46: 55-56.

Watson, J.D., 1952. The physiological basis of variation in yield. Adv. Agron, 4: 101-145. DOI: 10.1016/S0065-2113(08)60307-7

Yildirim, E., M. Turan and I. Guvenc, 2008. Effect of foliar salicylic acid applications on growth, chlorophyll and mineral content of cucumber (Cucumis sativus L.) grown under salt stress. J. Plant Nutr., 31: 593-612. DOI: $10.1080 / 01904160801895118$

Yokoyama, T., 1975. Text Book of Tropical Sericulture. 1st Edn., Japan Overseas Cooperation Volunteers, Tokyo. 